\title{
Yantras: algunas reflexiones sobre el arte hindú
}

\section{Yantras: Some Reflections on Hindu Art}

\section{Felipe Luarte Correa}

Centro de Estudios Asiáticos, Pontificia Universidad Católica de Chile. Santiago, Chile.

fluarte@uc.cl

\section{Resumen}

Más allá de su atractivo, el arte hindú nos resulta críptico. Esto se debe a que tratamos de comprenderlo desde nuestros propios parámetros culturales sin atender al contexto sociocultural y religioso específico en el que fue creado. A través del estudio general de los yantras, este artículo aborda los principios fundamentales, las normas y características predominantes en el arte hindú en relación con la tradición religiosa que le otorga sentido. Se sostiene aquí que solo un análisis de este arte como un todo entrega las herramientas necesarias para comprender su finalidad y simbolismo.

Palabras clave: arte, estética, yantras, hinduismo, India.

\section{Abstract}

Beyond its allure, hindu art seems cryptic to us. The reason why is that we try to understand it from our own cultural parameters, ignoring its sociocultural and religious context of origin. This article considers the general study of the yantras as a means to reflect on the fundamental principles, norms and characteristics of hindu art, in relation with the religious traditions that provides its meaning. We assert that only a comprehensive aesthetical analysis offers the tools to understand its purpose and symbolism.

Keywords: art, aesthetics, yantras, hinduism, India. 


\section{Introducción}

Toda cultura y, por ende, toda creación artística es consecuencia y heredera de una tradición que, a su vez, responde a una determinada concepción y cosmovisión de vida, a una autopercepción, a una única manera de conocer y relacionarse con el universo. En definitiva, a un grado de racionalidad que es particular en cada cultura y que la diferencia de otras. Así pues, asumámoslo ahora, sería inútil pretender encajar las distintas concepciones indias -e hindúes en particular- en los esquemas de Occidente que nos son familiares. Sin duda, más beneficioso sería dejar solo por un momento estos a un lado y permitir que el carácter profundamente -y en apariencia- extraño de estos pueblos "nos revele -tal como señalara el destacado indólogo Heinrich Zimmer- las limitaciones inconscientes de nuestra propia forma de enfocar los enigmas de la existencia y del Hombre" (22).

En las siguientes páginas trataremos el arte hindú, a través del estudio de las artísticas representaciones geométricas conocidas como yantras. Abordaremos también, tangencialmente, la filosofía religiosa (hinduismo) que ha nutrido por miles de años el espíritu de la India, y que se encuentra incorporada en todos los aspectos de la vida -espirituales y mundanos, místicos y eróticos, religiosos y seculares-, ya que el hinduismo nunca ha conocido la división entre lo sagrado y lo profano, distinción a la que estamos acostumbrados hoy en día en Occidente. ${ }^{1}$ Este modo de concebir la vida y de mirar el mundo se ve reflejado en un arte que, si bien se inspira en la naturaleza y afirma los placeres de la vida, es esencialmente espiritual, por lo que renuncia a toda semejanza con la realidad inmediata y a toda confirmación por parte de los sentidos.

De este modo, para apreciar en su totalidad el arte hindú, el observador-espectador occidental debe abandonarse a su verdadero espíritu, a su pura intuición, ya que de lo contrario "puede ofenderse por ser lanzado como una pelota del campo de la belleza exterior -preponderante en Occidente- al campo de la belleza interior (más propio de los pueblos orientales)", a la cual accedemos solo por una poderosa "necesidad interna de abandonar la belleza convencional" (Kandinsky 25, énfasis en el original). Como sostiene Kandinsky:

El espectador occidental está demasiado habituado a buscar la lógica exterior de los diversos elementos de la obra de arte. La etapa materialista ha modelado en la vida y, por ende, también en el arte, un espectador incapacitado para enfrentarse simplemente con la obra [...] donde todo lo busca en lo accesorio y superficial

1 Recordemos que los rituales religiosos son parte fundamental del día a día de cualquier hindú ortodoxo y practicante, además de que los propósitos mundanos, y no sólo los espirituales, también son parte del hinduismo, por lo que conviven y se relacionan entre sí permanentemente. Así pues, los cuatro grandes objetivos o metas del hinduismo (purușa-artha) combinan ambas esferas: la espiritual y la profana. De esta manera, vemos que artha (éxito y prosperidad material) y kāma (placer sensual y sexual), tienen un espacio reconocible y permitido en la vida del hindú, pero subordinados siempre a dharma (entendido como deber religioso) y moksha (liberación del samsāra, el ciclo de nacimiento, vida y muerte). 
(copia de la naturaleza, reconocimiento de esta a través del temperamento del artista, esto es, de su temperamento, espacialización, anatomía, perspectiva, ambiente externo y otros), excepto la vida interior de la obra y la repercusión sobre su sensibilidad (72-3).

Por el contrario, el arte tradicional hindú no conoce la frialdad de los museos y está lleno del fervor de los devotos. Para comprender sus templos, sus esculturas, su música, su arte sagrado en general, es esencial captar su finalidad con la sensibilidad de los fieles que los veneran. Debemos olvidar las teorías estéticas de nuestro Renacimiento: el arte por el arte, la expresión del artista, de su propia sensibilidad y de sus ideas individuales no tienen aquí ningún sentido ni cabida. Aplicar estos conceptos al arte tradicional hindú sería falsear su carácter y su razón misma de ser. Con su anonimato, los pintores y los escultores, los músicos y poetas demostraban que no querían personalizar sus obras, sino solo -y principalmente- servir a lo Sagrado, a lo Trascendente, a lo Absoluto, a la Última Realidad (brahman), ya que entienden -y experimentan- el arte y el goce de este, como uno de los modos que disponen los seres humanos para acercarse a la ultimidad por medio de tal deleite (Marchianò 157). Así pues, esta misión no les permitía ninguna fantasía personal que omitiera los cánones establecidos por la antigua tradición artística, pero así todo, y para desazón de las complejas teorías artísticas occidentales, el genio de India fue vencer estas fórmulas y normas y, a pesar de ellas, producir obras de arte magníficas (Rivière 49, 62).

Para comprender la estética del arte hindú, entonces, es necesario considerarla por encima de su aspecto formal e ir más allá, es decir, a sus fundamentos filosóficos y religiosos que le dan razón de ser y la sustentan. Para encontrar las leyes que han guiado al artista en la realización de su obra se deben consultar los numerosos y antiguos textos hindúes escritos en sánscrito, que tratan y describen el arte y la artesanía, sus reglas y principios, los cuales se encuentran compilados en los Śilpa Śāstra (la ciencia o tratados del arte y de la artesanía), así como también se debe considerar la actitud misma del pueblo de la India ante la vida, la religión, el amor y la muerte, expresada en muchas creaciones artísticas. Tales elementos nos proporcionarán el profundo sentido de este arte y nos permitirán comprender sus variados aspectos, sus distintos matices y su origen primordial.

En primer lugar, debemos considerar que existen en el pensamiento hindú constantes que han orientado invariablemente la evolución de su cultura y que volveremos a encontrar en su arte: la fuerza de su tradición, cuyo valor es indiscutible; también la autoridad de las escrituras sagradas -desde los Vedas en adelante-, que ha sido absoluta durante miles de años. Esto no hay que olvidarlo cuando nos sorprendamos de la ciega obediencia del artista respecto de los cánones eternos y sagrados de su arte (Merlo 59). En esencia, la fuerza de la tradición va a dominar tanto en el campo del arte como en el religioso, siendo más bien uno solo, por lo que para comprender uno, invariablemente hay que conocer el otro. 
De más está señalar que sería imposible acabar total y de buena manera con todas las preguntas, reflexiones, análisis y conclusiones que de por sí provoca el estudio de un tema tan complejo y amplio como el arte hindú. Por lo mismo, solo pretendemos presentar, asumiendo nuestros juicios preconcebidos y nuestras limitaciones culturales, algunas ideas y valores que sustentan un arte -y una cultura- diferente al nuestro, a través de la descripción de los yantras, en los límites espaciales permitidos de un artículo como este.

\section{Algunas consideraciones generales sobre el arte hindú}

Siempre resulta difícil abordar y penetrar el corazón de una cultura -también del arte, en este caso particular- distinta a la nuestra. Los prejuicios naturales se suceden rápida e involuntariamente, magnificando una distancia entre el "nosotros" y el "otro", creando una mirada recelosa, muchas veces también chocante, a todo lo que no nos sea reconocible a primera vista y, por tanto, a todo lo que no podemos clasificar como normal y familiar, siempre desde nuestros parámetros socioculturales. En muchos casos, el arte religioso de la India -ya sea hinduista, budista o jainista- nos asombra y nos intriga cuando por primera vez tenemos contacto con él, pero también en otras ocasiones nos produce cierto rechazo. Ambas reacciones se deben a la total ignorancia y desconocimiento que tenemos de las teorías del arte indio, así como también de sus culturas y religiones que lo fundamentan y le dan vida y sentido.

De este modo, para analizar ciertos temas, es necesario antes estudiar otros que nos permitan un mayor acceso, amplitud y comprensión de los contenidos principales. Así pues, para comprender el arte hindú y los yantras, es indispensable antes conocer su significación espiritual, analizándolos como un todo, ya que existe una gran unidad en todas las formas de su cultura, en su estética y en el propósito espiritual que las anima (Merlo 19). Una aspiración espiritual que fue $-\mathrm{y}$ en parte continúa siendo, sobre todo en los ámbitos más tradicionales- la fuerza directriz de esta cultura, su centro de pensamiento, también su pasión. Los hindúes sólo hicieron de la espiritualidad el más alto e importante objetivo de la vida, sino que trataron, hasta donde pudieron, de volcar toda la vida hacia la espiritualidad, pero sin negar o rechazar el mundo sensorial. Es este el sello que deja marcada en la India todas las formas de su cultura y quehacer humano.

Así pues, para comprender el arte hindú debemos, obviamente, acercarnos primero a lo que es el hinduismo. ${ }^{2} \mathrm{El}$ hinduismo no es solo una religión ni un sistema

2 Para una general e introductoria aproximación al hinduismo, sus principales características prototípicas, historia y evolución, ver Biardeau, El Hinduismo; Flood, El Hinduismo; Shattuck, Hinduismo, y Luarte, "El Hinduismo: Consideraciones históricas y conceptuales". 
fijo de pensamiento, sino más bien es una filosofía, que también contiene ciencia y psicología, además de poseer una serie de postulados producto de la revelación divina y de la experiencia pura e intuitiva vivida por sus distintos yoguis (yogì), sādhus, samnyāsis y rishis (rși en la meditación y en las prácticas ascéticas, y que desde los antiguos tiempos de los Vedas -mediados del segundo milenio antes de Cristo-, pasando por los Upanișds -alrededor del 800 a.c. en adelante- y otras escrituras sagradas posteriores, junto con la milenaria y rica tradición de enseñanza e iniciación espiritual del guru o maestro al discípulo, ha ido creciendo y desarrollándose hasta dar forma a un vasto, complejo y variado conjunto de textos sagrados, filosóficos, metafísicos, mitológicos y épicos (Jansen Ix y x). Con una lógica perfecta, explica cómo está conformado el mundo fenoménico y describe con gran claridad los distintos procesos y condicionamientos mentales, junto con los métodos para desacondicionarse e ir más allá de estos: hacia la Verdadera Libertad (mokșa), hacia nuestra verdadera esencia y real Ser, sat-cit-ānanda, es decir, Existencia, Conciencia y Beatitud (Luarte). A veces, se confunde solamente con religión porque es un camino que apunta al desarrollo espiritual del ser humano, que además tiene monjes y monasterios. Pero estos monasterios surgen solo por la necesidad de aislarse para la realización de las prácticas de meditación (dhyāna) y otras de devoción (bhakti).

Según el Sanātana Dharma, ${ }^{3}$ los mundos divinos y el humano se encuentran en permanente contacto, y no existen grandes diferencias entre ambos, más bien el Hombre (microcosmos) y el Universo (macrocosmos) serían una réplica perfecta, una ilusión para algunos o, para otros, una manifestación de la Realidad Absoluta y Suprema, de brahman.

Y el Arte (con mayúscula), por supuesto, no estaría ajeno tampoco a esta concepción de la realidad, a la realización en vida de la única y más importante verdad: la de que cada hombre es Aquello (tat tvam asi: Tú eres Eso), es decir, brahman, el Todo y el Uno sin segundo (Coomaraswamy, La Danza de Siva 41). Por ejemplo, en la concepción de la obra de arte tradicional hindú -ya sea en la arquitectura, en la plástica, en la música, en el teatro o en la danza- es necesario que la creación tome nombre: se le da vida, se le abren los ojos y se le hace, finalmente, Dios; tan real y tan presente como el arquetipo espiritual (Coomaraswamy, La Transformación 119 y 120; Merlo 46; Jansen 13). De este modo, "el aspecto profano del arte de la India es solo formal: es la reproducción del mundo divino en su inspiración más profunda" (Coomaraswamy, La Transformación 127).

Así pues y desde esta perspectiva, todo arte es en definitiva, voluntaria o involuntariamente, consciente o inconscientemente una contemplación de lo divino en su aspecto más deleitable, que se manifiesta en forma de belleza. En efecto, según

3 Sanātana Dharma es el nombre tradicional para lo que comúnmente conocemos como hinduismo, que podría ser traducido como religión (dharma) eterna (sanātana) y que agrupa diversas -y a veces contrarias- tradiciones y corrientes de pensamiento y prácticas nacidas en la península índica 
la teoría estética hindú, la belleza es el esplendor del paramātmā (Suprema Alma) a través de la materia. Únicamente el alma y todo lo que le concierne es verdaderamente hermoso y digno, por tanto, de ser representado en las distintas artes. De este modo, la belleza de la naturaleza es solo el burdo e incompleto reflejo de la belleza natural del Gran Espíritu (mahāpuruṣa), pero, así y todo, fundamental para conocer y comprender las grandes verdades ulteriores de la existencia humana y del universo en general.

Por tal razón, podríamos afirmar que el arte hindú es ante todo un yoga (ŚilpaYoga), en el sentido de que es un camino, una actividad meditativa-contemplativa de carácter devocional, orientada hacia la divinidad; una técnica espiritual de identificación y, finalmente, completa absorción entre el sujeto y el objeto, entre el conocedor y lo conocido, entre la materia y el Espíritu -prakrti y puruṣa-, en un UNO indistinto y permanente, que nos aleja en distintos grados del mundo fenoménico y de sus opuestos. ${ }^{4}$ En definitiva, el arte hindú es un medio - un camino y una disciplina- para alcanzar la armonía o unidad de la conciencia (Coomaraswamy, La Danza de Siva 20), ya que por medio de la experiencia estética, como también a través de la experiencia mística, se nos revela la verdadera naturaleza de la realidad y de la conciencia que la percibe. Ese es su sentido y meta última:

En otras palabras, lo bello solo es la percepción del infinito por y a través de lo finito. De este modo, la percepción de lo bello exige que el artista -su espíritu, su verdadera y última esencia- sea puro y bello también, carente de ego, pues no es el propio artista el que produce la belleza por sus conocimientos y/o su impecable técnica, sino que es la Idea de la belleza la que actúa a través de él. ${ }^{5}$ Todo arte verdadero es, pues, solamente la exaltación de la belleza del Señor por medio de las palabras, las formas, los actos, la música, entre otras, no existiendo nada más importante, digno y de mayor valor para ser representado en este mundo (Merlo 50-7).

Así se entiende que el artista hindú deba ser un yogui (śilpin yogī) ante todo: un purificado, un aspirante y buscador espiritual, un vidente. Según la tradición indiahindú de los Śilpa Śāstra, el artista creador es el que conoce y comprende los Vedas -además, lógicamente, de los propios Śilpa Śāstra-. Con tal conocimiento, el artista debe retirarse a un lugar solitario la noche anterior al comienzo de la obra y, tras un ritual de purificación, se le instruye en la oración: “Oh Tú, Señor de todos los Dioses,

4 Para conocer y entender el yoga en un sentido amplio y general, desde los distintos tipos, finalidades y evolución, ver Shrimad Bhagavad Guita. Diálogos con lo Eterno (comentarios de Swami Sivananda). Deshapande, El auténtico Yoga, 2001. Para una visión desde la perspectiva occidental, ver Eliade, El Yoga y Samuel, The Origins of Yoga and Tantra.

5 Según el pintor ruso Kandinsky: "el artista construye misteriosamente la auténtica obra de arte a través de una vía mística. Aislada de él, ella toma vida propia y se constituye en algo individual, una entidad independiente que respira en forma autónoma y posee una existencia material real" (81). Compárense las similitudes y la unidad de fondo entre estas palabras y la filosofía artística hindú, a pesar de las diferencias espaciales y temporales. 
muéstrame en sueños cómo plasmar la obra que tengo en la mente" (Coomaraswamy, La Danza de Siva 23).

Si el artista logra esta condición, es decir, es piadoso y perfecto, si vive siempre en lo divino, la cristalización de sus pensamientos hacia Dios, finalmente, lo transforman y lo transfiguran, lo vuelven uno con Él (brahman), aunque solo sea por el momento mismo y único de la concepción y creación de la obra de arte. El espíritu del artista debe ser purificado hasta tal punto que todas las influencias estéticas y filosóficas puedan reflejarse por completo en él de manera no buscada, inconscientemente; debe quedar vacío para que la Idea le colme por completo (Merlo 55-6). De este modo, al encontrarse el artista en dicho estado de meditación y de contemplación profunda en su silencio interior, se encuentra allí con su mundo ideal, el mundo de las ideas arquetípicas -común a todos los hombres, de ahí el carácter universal del arte puro y verdadero, más allá de las apreciaciones estéticas particulares de cada cultura o tradición artística-, que luego representa en la obra.

El arte concebido así es la plataforma de lo divino y esencialmente religioso, por lo que las diferencias en la calidad de las obras artísticas proceden más bien de la propia naturaleza profunda del artista, quien sería más o menos apto - no solo en el sentido estético ni técnico, sino principalmente en su preparación en el ámbito de la pureza interior y en su anhelo por la realización espiritual- para sentir y expresar el espíritu a través de su experiencia estética individual, la cual siempre es de carácter general, colectiva y universal.

Siguiendo con los textos tradicionales, para el artista el proceso técnico consiste, por lo tanto, en crear, por medio de la concentración, la introversión y la meditación (dhyāna yoga), el necesario vacío mental en sí mismo -no en un sentido nihilista, sino que en una ausencia de todos los condicionamientos mentales y de las limitaciones sensoriales-. Con esta concentración del espíritu creador se logra penetrar en las fuentes mismas de la vida que existen en el propio artista y se alcanza, por este tipo de yoga, el cese de toda actividad mental y la transformación del equilibrio cinético en estático. Una vez conseguido este vacío mental, esta total plenitud y paz espiritual, el artista debe invocar a la divinidad que quiere representar. Debe meditar profunda y largamente sobre la forma de esa divinidad, de tal manera que su imagen irá, poco a poco, tomando forma en su propio espíritu. Imagen que, finalmente, copiará y reflejará en su obra de la manera más pura y transparente posible.

En otras palabras, podríamos señalar que lo que el artista hindú hace -o más bien dicho, deja de hacer-, en términos prácticos y concretos, no tiene mayor relevancia para la obra en sí. Lo realmente importante, además de respetar los lineamientos especificados en los Śilpa Śāstra, es el proceso que se produce desde el corazón o alma del artista -conciencia absoluta e iluminada- hacia la conceptualización de la forma del objeto a representar en su mente -en la conciencia sutil- con el fin de ser manifestada física y materialmente en el plano de la conciencia burda. 
En esencia, cuanto más pura sea la mente del artista, con más fidelidad podrá reflejar la beatitud divina, es decir, la fuente creadora de lo bello. La belleza en el alma del artista es lo que finalmente se refleja o proyecta en las formas materiales de su creación. Nada más ni nada menos. En términos filosóficos hinduistas, "es la revelación del Yo divino (ātma) en la forma (rūpa). La belleza es la presencia encarnada del Ser en la creación del artista" (Rivière 52). De esta manera, la belleza de su creación dependerá, exclusivamente, de su poder de concentración yóguico, de su talento y de su arte. Si su visión interior ha sabido captar lo infinito, si ha percibido la esencia de los mundos sagrados a través de la vida espiritual, podrá sentir también la presencia de lo divino en el mundo material y fenomenológico, y no por medio de otra forma o método.

El verdadero arte, según las normas estéticas hinduistas tradicionales, tiene su principio en la imitación de las distintas manifestaciones de Dios en la naturaleza. No se trata en lo absoluto, sin embargo, de una simple copia y sin sentido de la realidad física. El artista debe penetrar en el mismo corazón del objeto e interpretar sus propias reacciones subjetivas ante la esencia de este sujeto en un éxtasis que se produce del contacto con lo divino inherente en cada cosa creada (Merlo 42-7). La finalidad de todo arte consiste en espiritualizar al hombre y acercarle a la fuente suprema de la manifestación, origen y causa del todo y de la nada. Cuanto más se remonte el artista en la escala de su acercamiento a Dios, más se espiritualizará, y más puro quedará de toda pasión y de todo egoísmo: se hará indiferente al juego del mundo. En resumen, la creación artística en el hinduismo no es hacer algo de la nada o crear una cosa de otra, sino proyectar el ser en las condiciones de espacio y tiempo propios y necesarios para el conocimiento del hombre por medio del intelecto. Así pues, la creación ya no es un mero proceso mecánico, un acto de hacer, sino un acaecer en los términos y en las formas de la última existencia consciente. De esta forma, el arte entendido como yoga -tanto para el creador como para el espectador- constituye un camino de reunión o reunificación, y "la experiencia que procura debe su carácter gozoso, su deleite, al proceso desindividualizador que mediante ella se lleva a cabo [...]. Sin desindividuación propiamente dicha no hay placer estético" (Fernández 47).

Como hemos vislumbrado ya, el arte tradicional hindú difiere tanto en forma y fondo con el promovido por la modernidad occidental, pero no así con el arte religioso premoderno de Occidente, con el cual comparte el carácter religioso y la finalidad de comunión con lo divino y lo sagrado. Las diferencias entre nuestro arte contemporáneo y el hindú se pueden explicar por las diferentes teorías estéticas que hay detrás de cada uno, las cuales, a su vez, responden al grado de conciencia en el cual cada uno ha nacido y se ha desarrollado. ${ }^{6}$ A riesgo de simplificar en demasía

6 Para profundizar en estos temas, el sentido del arte y los cambios en la función de éste a través del tiempo, ver Luis Osvaldo F. de Castro. El arte en la ruta del hombre. 
la compleja estética hindú, permítaseme abordarla sucintamente en algunas pocas líneas a continuación con el fin de entregar una visión más completa de este tipo de arte, así como también continuar profundizando en su fundamento y sentido.

La estética hindú se desarrolla en la teoría del Rasa o del placer estético, que encontramos por primera vez sistematizada en el Nàtya-Śāstra (Ciencia del Teatro o Tratado sobre Teatro, que también integra música, danza, canto, pantomima y sus efectos escénicos), el cual ha recibido el título de "quinto Veda" (pañcamaveda) por estar basado en el Nātya-Veda (Conocimiento del Teatro): un "texto atemporal y revelado" como todos los Vedas, expuesto y transmitido oralmente a través del tiempo, hasta su compilación formal en el Nātya-Śāstra, atribuida al sabio Bharata (Bharata Muni), hacia los siglos II y IV d.c. Su concepción como Veda nos demuestra claramente que el drama indio tradicional fue visto como algo perteneciente al ámbito religioso y no únicamente a la entretención. Si bien el disfrute sensorial es un efecto no solo permitido, sino que también deseado en la creación y realización de las distintas manifestaciones artísticas, siempre se encuentra subordinado a su fin último: "producir" en el individuo un estado o sensación de absoluta verdad (existencia), conciencia y felicidad (sat-cit-ānanda).

Según el Nàtya-Śāstra, el teatro tiene dos objetivos: la instrucción y el gozo (vyutpatti y rasa, respectivamente). "A este Veda [...] no se accede por la vía normal (como sí sucede con el Rg, Sāma, Yajur y Atharva Veda) la de la iniciación y el estudio -larga, austera, sagrada y reservada a los dvijas o dos veces nacidos-: en cierto sentido este nuevo Veda es un Veda sustituto que debe instruir al divertir" (L. Bansat-Boudon, cit. en Figueroa 159), al momento de narrar historias de carácter religioso y mitológico, que deben "normar la conducta de aquellos que, de acuerdo con la perspectiva elitista brahmánica, ponen en riesgo la estabilidad social y cósmica al entregarse a prácticas obscenas" (Figueroa 158). Además, como todo Veda, el Nātya-Śāstra cuenta también con un tradición de exégetas que aclaran su mensaje, donde quizás el más importante sea el Abhinavabharati de Abhinavagupta (siglos IX-X) de la escuela shivaísta de Cachemira.

La vital importancia de este texto para el estudio del arte hindú radica en la preponderancia que posee el teatro - por atraer la vista y el oído simultáneamente- entre todas las expresiones o manifestaciones artísticas. Además, para los indios de la antigüedad, "la poesía es la forma más elevada de arte y el drama es la forma más elevada de poesía. Por ello, en la India, el problema de la estética en tanto que filosofía del arte se ha estudiado, no por referencia a la música o la representación plástica o pictórica, sino principalmente en el contexto de la representación dramática" (Pandey 1). De este modo, el origen de la teoría del Rasa (Rasa-Sūtra), si bien nace de la experiencia del teatro como un acto lúdico-sacrificial de creación de "mundos", desde ahí se extiende y es aplicable al resto de las artes antiguas de la India, tales como la escultura, la pintura, la literatura y, por supuesto, al teatro, la danza y la música. 
En esencia, el Rasa-Sūtra trata sobre la emoción estética y el poder evocador de una obra en el lector o espectador (rasika). Así pues, Bharata nombra, en el capítulo seis del Nātya-Śāstra, ocho estados mentales básicos (sthāyibhāva) del ser humano, que son: el amor, la risa, el dolor, la cólera, el valor, el miedo, la aversión y la admiración. Dichos estados producen ocho emociones estéticas o rasas, derivadas de las anteriores, que corresponden, respectivamente, a lo erótico (śringāra), lo cómico (hāsya), lo compasivo (karuna), lo furioso (raudra), lo heroico (vīra), lo terrible (bhayānaka), lo repúgnate (bībhatsa) y lo maravilloso (adbhuta). Posteriormente, Abhinavagupta en su obra Abhinavabharati complementó -por decirlo de alguna manera- el texto de Bharata, sumando una emoción más: śānta (paz) rasa, cuando el místico y esteta de Cachemira comparó la experiencia estética con la experiencia mística y, asimismo, la del placer estético con la pura y absoluta felicidad (ānanda), que vive el alma individual al (re)conocer a brahman (Maillard y Pujol 1999). De esta manera, śānta-rasa es el mahā-rasa, principio estético central de los restantes valores, que le otorga sentido y su finalidad última: la verdadera contemplación del àtma, es decir, silencio, paz y gozo en su estado de mayor pureza e intensidad, como parte y esencia del absoluto. Con esto, el aporte de Abhinavagupta estableció oficialmente las bases filosóficas del arte hindú como un yoga, como un camino a la unión divina: ${ }^{7}$

Toda experiencia auténticamente placentera, especialmente desde la perspectiva tántrica, es una experiencia unificadora, una reunión de lo diverso y un modo de retorno a la unidad. La individualidad y la diferenciación, la limitación, en definitiva, son, en cierto modo, trascendidas en toda verdadera experiencia de placer, experiencia unitaria. El placer es retorno al origen [...]. En este sentido, el gozo estético sólo se caracteriza por el medio específico (de tipo sensible y formal) a través del cual se canaliza la reintegración de la individualidad que tiene lugar en toda experiencia placentera (Fernández 47).

Además, como todo "arte puro" que apela a la espiritualidad del ser humano, el arte hindú está esencialmente basado en la ciencia del simbolismo, por lo que no se puede comprender ni apreciar en su totalidad sin conocer antes la literatura religiosa y el pensamiento filosófico al que refiere. El símbolo es el único instrumento por medio del cual el artista transmite al espectador $u$ oyente las verdades superiores y, asimismo, solo por medio del símbolo, el observador es capaz de relacionar intuitivamente un aspecto del mundo sensible con el mundo suprasensible (Merlo 24-6). La necesidad de tales soportes deriva del hecho de que "lo imperceptible para el ojo o el oído no puede ser captado objetivamente tal como es en sí mismo, sino

7 Para profundizar en śānta-rasa y en la estética de Abhinavagupta, ver Masson y Patwardhan, Śāntarasa and Abhinavagupta's Philosophy of Aesthetics. 
solamente en una semejanza. El símbolo debe ser naturalmente adecuado, y no podría ser elegido al azar. Se infiere lo invisible en lo visible, lo inaudible en lo oído" (Coomaraswamy, Hinduismo 34).

De tal manera, la iconografía hindú es una representación simbólica de los conceptos de dioses y diosas y de sus múltiples atributos. Estas divinidades son consideradas como representaciones concretas, en el tiempo y en el espacio, de los conceptos abstractos del ser. Pero el ser solamente se revela en las formas y en los nombres, con todas las imperfecciones y limitaciones inherentes a la manifestación material. Los símbolos concretos que el ser humano empleará serán, pues, los pobres medios que utilizará para traducir lo inefable. La Darsánopanishad dice: "el yogī ve a Śiva [Dios] en el Yo, pero no en las imágenes; las imágenes han sido creadas para ayudar a la contemplación de los ignorantes" (cit. en Rivière 62). Los símbolos son, por ende, necesarios solo en un primer momento para entender y extender los conceptos sutiles en el espíritu de los demás; sin embargo, una vez que se ha alcanzado y conocido la verdadera realidad, la esencia última de las cosas, son dejados a un lado antes de que nos sea dado transformarnos en ello, puesto que ya no son útiles ni imperiosos (Coomaraswamy, Hinduismo 34). El arte hindú establece para el devoto una aproximación espiritual, intelectual y física a la divinidad. La imagen es una manifestación y/o presentación de la divinidad a través de una obra de arte concreta, y el monumento es, al mismo tiempo, su cuerpo y su mansión.

Por otra parte, hallamos la permanente búsqueda de leyes fundamentales de la filosofía hindú, lo que ha repercutido en que su arte ha intentado integrar siempre las formas geométricas y arquitectónicas, en arquetipos. La geometría se considera como un plano de refracción entre el mundo de las ideas y el de la manifestación visible y terrenal. Esto también aplica para los yantras. Por ende, y más allá de la reiteración, es fundamental reconocer que el conocimiento de los símbolos y sus significados resulta indispensable para comprender un arte que no está basando en las percepciones físicas de los sentidos, sino en fundamentos espirituales y religiosos, en un concepto psicológico de la creación artística, en un mundo "enmascarado" por el universo fenomenológico aparente. Para penetrar en este mundo, el símbolo es indispensable y posee una doble finalidad: en primer lugar, consigue que el mismo artista realice en una forma concreta la idea abstracta que debe encarnarse, mediante su mano, en la materia. Y segundo, hace que el pueblo pueda comprender la idea abstracta por el valor tradicional y frecuentemente universal del símbolo. Así, dirige, orienta y regula la expresión de la idea en la materia: el genio del artista goza de plena libertad para crear la obra de arte en los límites del símbolo (Coomaraswamy, Hinduismo 47-9). Si obedece tradicionalmente a las normas estrictas del arte descritas en los Śilpa Śāstra, su libertad de expresión es total dentro de estas reglas. 


\section{Yantras: representaciones geométricas de Dios}

Ahora bien, teniendo siempre presente las ideas mencionadas anteriormente, nos encontramos, en parte, preparados para adentrarnos en el estudio específico de los yantras: obras que en apariencia no son más que complicados y, algunas veces, confusos dibujos geométricos, realizados por lo general en el suelo y tradicionalmente en la tierra, pero también se dibujan en papel, madera o tela, e incluso otros se graban en metal o se diseñan en dimensiones en barro o en arena. En su intrincada composición lineal, los yantras hacen referencia directa a ciertas representaciones de niveles y energías del cosmos, expresadas a través de una deidad determinada y/o también del cuerpo humano por ser una réplica microcósmica del macrocosmos (Khanna). Antes de continuar con el tema de los yantras, debemos considerar que:

Para el hombre religioso [en este caso el hombre hindú], la naturaleza nunca es exclusivamente "natural": está siempre cargada de un valor religioso. Y esto tiene su explicación, puesto que el Cosmos es una creación divina: salido de las manos de Dios, el mundo queda impregnado de sacralidad [...] El mundo se presenta de tal manera que, al contemplarlo, el hombre religioso descubre los múltiples modos de lo sagrado y, por consiguiente, del Ser [...] No hay que olvidar que, para el hombre religioso, lo "sobrenatural" está indisolublemente ligado a lo "natural", que la naturaleza expresa siempre algo que la trasciende (Eliade, Lo Sagrado 87-8).

Todo esto cobra sentido solamente en el contexto de una concepción espiritual-esotérica de la realidad, donde "el espacio no es homogéneo; presenta roturas, escisiones: hay porciones de espacio cualitativamente diferentes de las otras [...] Hay, pues, un espacio sagrado y, por consiguiente, fuerte, significativo, y hay otros espacios no consagrados y, por consiguiente, sin estructura ni consistencia; en una palabra: amorfos" (21). En esencia, se deben sacralizar los espacios, cualquiera sean estos, para así producir una ruptura con el pasado profano del lugar con el fin de que comience una nueva vida: comienzo que tendrá que ser establecido por las escrituras sagradas y por los astrólogos-sacerdotes (brāhmanas), que saben ver cuándo los astros son propicios para tales actos de creación.

Esto último es de gran importancia, ya que la función de la astrología no puede ser menospreciada si queremos entender realmente la tradición hindú en su conjunto. La relevancia de los principios metafísicos que entregan las bases del arte de tradición védica se hallan impregnados de consideraciones, normas y reglas estructurales, que contemplan el comienzo exacto de la realización de la obra, por ejemplo, solo en lugares y momentos precisos y propicios, que se fundamentan bajo determinadas posiciones y alineamientos de las estrellas y de los planetas (Boner et al.). Si bien es cierto que dichas leyes se remontan a un pasado indefinido, y son transmitidas oralmente en un comienzo, se hallan compiladas en el Vāstu Sāstra, 
donde destaca especialmente el texto Brhat Samhita -recopilado por el astrónomo, matemático y astrologo indio, Varāhamihira, a mediados del siglo vI-, el más antiguo de los fechados hasta el momento. También el Vishnudharmottara Purana del siglo viI, que versa sobre cosmología, cosmogonía, astronomía y astrología, junto también con la división del tiempo y a las reglas de la retórica, de la métrica, del teatro y de la danza, además de la música y de la pintura (Kramrisch 3-5). Y, finalmente, el Tantrasamuccya, perteneciente ya al siglo xv. Así pues, y tal como afirma Stoler, el Vāstu Śāstra es, en definitiva, astrología aplicada (271-2). ${ }^{8} \mathrm{Al}$ mismo tiempo, en un plano más "interno y personal", el yantra se concibe y se traza como un soporte para la meditación; más exactamente, para una visualización concentrada y una íntima experiencia interior del juego polar y de la paradoja rompedora de toda lógica de la eternidad y del tiempo. Pero antes de que llegue a revelar su significado, y de que el espíritu empiece a experimentar sus efectos, el observador debe comprender la relación exacta de su conciso trazado con los principios básicos de la metafísica hindú (Zimmer 137-8). Esta composición resume, en un simple y único momento, todo el sentido de la mitología, de la metafísica y de las filosofías hinduistas ortodoxas.

Pero, ¿qué significa el término Yantra? La palabra sánscrita yantra proviene de la unión del prefijo yan o yam, con el sufijo tra, el cual se utiliza en sánscrito para formar sustantivos que designan instrumentos o herramientas. Por ejemplo, khan significa cavar, khani excavar o arrancar de raíz; y khanitra es una herramienta para cavar, como una pala o un palo plantador. Asimismo, man -relacionado etimológicamente con mental- significa pensar o tener en la mente; por tanto, mantra es un instrumento para evocar o producir algo en nuestra mente, concretamente, una fórmula sagrada o encantamiento mágico para evocar o traer a la mente la visión y la presencia interior de un Dios. De igual manera, yantra es un instrumento para hacer yan o yam. Si continuamos con la definición, observamos que el prefijo yan o yam, significa contener, someter, gobernar o controlar. El verbo yan o yam, de este modo, significa adquirir control sobre la energía inherente a algún elemento o ser (Monier-Williams 845). ${ }^{9}$

Así pues, la palabra yantra designa, en primer lugar, cualquier tipo de máquina y/o artefacto construido para producir energía con la finalidad que se le ocurra al hombre. En la tradición devocional hindú, yantra es un término general que designa los instrumentos del culto, a saber: ídolos, cuadros o diagramas (mágicos) geométricos. Un yantra puede servir: 1) de representación de alguna personificación o aspecto de lo divino; 2) de modelo para el culto de una divinidad inmediata al corazón, una vez que el iniciado devoto ha desechado la parafernalia del ritual externo (ído-

8 Ver también Boner et al. 35-42, Merlo 63-5.

9 La definición etimológica de yantra, así como también las distintas definiciones y/o traducciones de todas las palabras y conceptos en sánscritos mencionados en este artículo, han sido tomadas de Monier-Williams, $A$ Sanskrit-English Dctionary. 
los, perfumes e inciensos, fórmulas pronunciadas de manera audible, entre otras); 3) y, finalmente, como una especie de mapa o plano de la evolución gradual de una visión, en tanto identifica al Yo con su contenido, el cual va variando lentamente, es decir, con la divinidad en todas sus facetas de transformación, donde el yantra contiene elementos dinámicos (Zimmer 138).

De esta manera, un yantra es un instrumento destinado a contener las fuerzas psíquicas concentrándolas en un dibujo, de modo que el poder visualizador del devoto sea capaz de llegar a reproducirlo. Es una máquina para estimular las visualizaciones, meditaciones y experiencias internas, inspirando una visión estática de la divinidad que se debe adorar, así como también de la presencia sobrehumana que se debe realizar o que puede dar lugar a una serie de visualizaciones que surgen y se despliegan unas detrás de otras en tanto eslabones o pasos de un proceso mayor (Monier-Williams 845). Según Zimmer, este segundo caso es más interesante, y más exigente para el iniciado, ya que funcionando en dos direcciones simultáneamente:

Primero hacia delante, como el curso de una evolución; luego hacia atrás, como un proceso de involución, deshaciendo las visiones previamente desplegadas. Es decir, repite en miniatura las etapas o aspectos de la manifestación del Absoluto en la evolución e involución del mundo. Además, requiere el poder visualizador por parte del devoto para seguir las dos trayectorias de este doble proceso de creación y disolución: por un lado, como desarrollo temporal y espacial; pero por el otro, como algo que trasciende las categorías de espacio y tiempo, como una simultaneidad de aspectos antagónicos en una única Esencia. Así, mientras de un lado los diagramas dinámicos sugieren un proceso continuo de expansión del centro del dibujo a la periferia y exigen el paso del tiempo para su curso, por otro han de entenderse como una jerarquía duradera, o un escalonamiento de grados del ser que se manifiestan simultáneamente, con el valor más alto situado en el centro. Estos grados simbolizan las diversas transformaciones o aspectos del Absoluto en el plano fenoménico de la Maya-Śakti -el poder creador-, y al mismo tiempo proporcionan un análisis pictórico de la estructura alma-cuerpo del hombre; porque la Esencia altísima (brahman), núcleo del mundo, es idéntica del Yo altísimo (ātma), médula de la existencia humana. Por tanto, las visualizaciones, las meditaciones y experiencias generadas por el yantra deben considerarse, no sólo como reflejos de la Esencia Divina en su producción y destrucción del Universo, sino al mismo tiempo (dado que los procesos del mundo y las etapas de la evolución se duplican en la historia y en la estructura del organismo humano) como emanaciones de la psique del devoto. Cuando se utilizan en relación con la práctica del yoga, los contenidos del diagrama yantra representan etapas de conciencia que conducen del estado diario de ingenua "ignorancia", a través de la experiencia yoga, a la realización del Yo Universal, Brahman-Ātma (139-40). 
Entonces, hasta el momento, tenemos que los yantras pueden ser utilizados por los devotos principalmente con dos propósitos, que si bien no se encuentran completamente separados entre sí, tanto en su forma como en su esencia, tienen ciertas diferencias en sus objetivos últimos, en sus distintos grados de profundidad y alcances, así como también en sus ejecutores.

Estos son, en primer lugar, los yantras que tienen mayor relación con el espacio en sí mismo, que podríamos considerar de una índole más cotidiana, normal, más simples y externos en cierto sentido, pero no por eso menos sagrados e importantes para la rica y variada ritualidad hindú. En estos, Dios

se puede manifestar bajo innumerables formas, también puede aparecer en cualquier lugar que desee y así convertir ese lugar en un sitio para celebrar actos rituales. Un Dios puede ser invitado a descender en un lugar determinado mediante diagramas especiales, para poder ser adorado allí. Dibujar ese yantra es en sí un acto sagrado. El principio divino está contenido en el yantra, que se representa en un plano bidimensional, aunque en realidad es tridimensional [...] Las fórmulas sagradas o mantras (que acompañan el "acto de creación”) han de ser pronunciadas en un orden, tono y ritmo especiales, mientras se cantan cuando el yantra se está dibujando y Dios está siendo evocado (Jansen 10).

Este tipo de yantras, realizados en un suelo previamente limpiado y purificado con agua y excremento de vacas, se efectúa principalmente en las entradas de las casas, de los templos o de lugares especiales, por medio de una pasta de arroz -principal alimento de la dieta hindú y, por consiguiente, cargado con cierto poder mágico y sagrado para ellos-, de polvos de distintos colores y/o con pétalos de flores variadas. La mayoría de las veces, el arte de pintar este tipo de yantras en el piso en la India rural y tradicional es una prerrogativa de las mujeres - práctica enseñada de madre a hija-, que comienza alrededor de los cinco o seis años, cuyo entrenamiento finaliza cerca de los veinte:

El arte de pintar en el piso es un arte que puede ser practicado tanto por una brahmâñ̄ (mujer perteneciente a la varna sacerdotal de los brähmana), como también por una que no lo sea. [...] El diseño, el estilo y el sentido de este tipo de yantras ha sido aprendido por las mujeres desde las tradiciones más antiguas, desde los orígenes mismos del Brahmanismo -sin pertenecer a ninguna secta en particular-, pero pueden, sin embargo, diferir según la región y el tiempo en que se desarrollen (Stoler 105-7).

Así tenemos, por ejemplo, que los yantras realizados en el sur de India son bastante más complejos y elaborados que los compuestos en la zona centro-norte del subcontinente indio; pero en todos, con mayor o menor dificultad, encontramos siempre la invocación de la presencia de una divinidad específica del lugar y de la energía presente en el interior de la persona que ha realizado el diagrama. También hallamos 


\section{FIGURA 1}

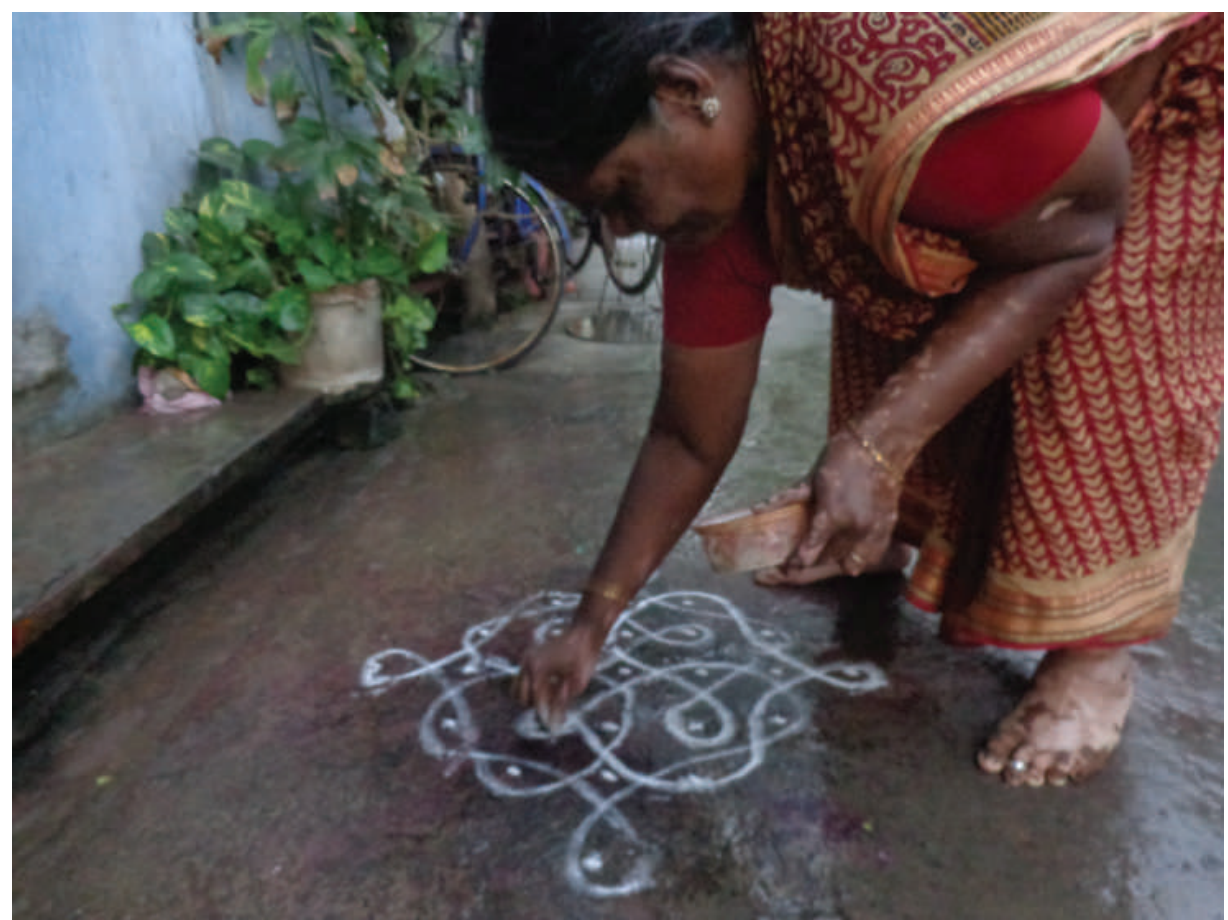

Mujer realizando un kolam afuera de su casa en Puducherry, ex Pondicherry, sur de la India. Fuente: Newsthali, 2013.

elementos y símbolos que evocan a la Madre Universal o a la Gran Diosa -Śakti-, como son las huellas de sus "Sagrados Pies" o ciertas figuras -el sol, la luna, las estrellas, entre otros- que representan el poder creativo de Ella, su propia creación y las fuerzas dinámicas que se mueven en todo el universo.

Por lo general, estos distintos diagramas mágicos, conocidos en India con variados nombres dependiendo de la región -tales como panjara, kolam, golam, manda$n a$, aripan, entre otros- y que entre ellos tienen algunas diferencias formales pero no de fondo, son realizados durante cada amanecer y/o atardecer. Otros son ejecutados en festividades religiosas y/o también durante cada saṃskāra, es decir, durante cada iniciación, sacramento o rito de paso de un estado de la vida a otro. Esto ocurre, por ejemplo, en el nacimiento de un niño; durante el upanayana, la iniciación de los "dos veces nacidos" de las tres primeras varnas -en simples palabras, castas y/o grupos sociales-, con la consagración y posterior postura del "cordón sagrado" (yajnopavita); en el matrimonio y, por último, durante los ritos funerarios. Así mismo, muchos hindúes realizan estos diseños solo como actos devocionales o en ciertos días del año sagrados para el almanaque lunar hindú, como son los días de ekādaśí, dedicados a la deidad Viṣnu. 
FIGURA 2

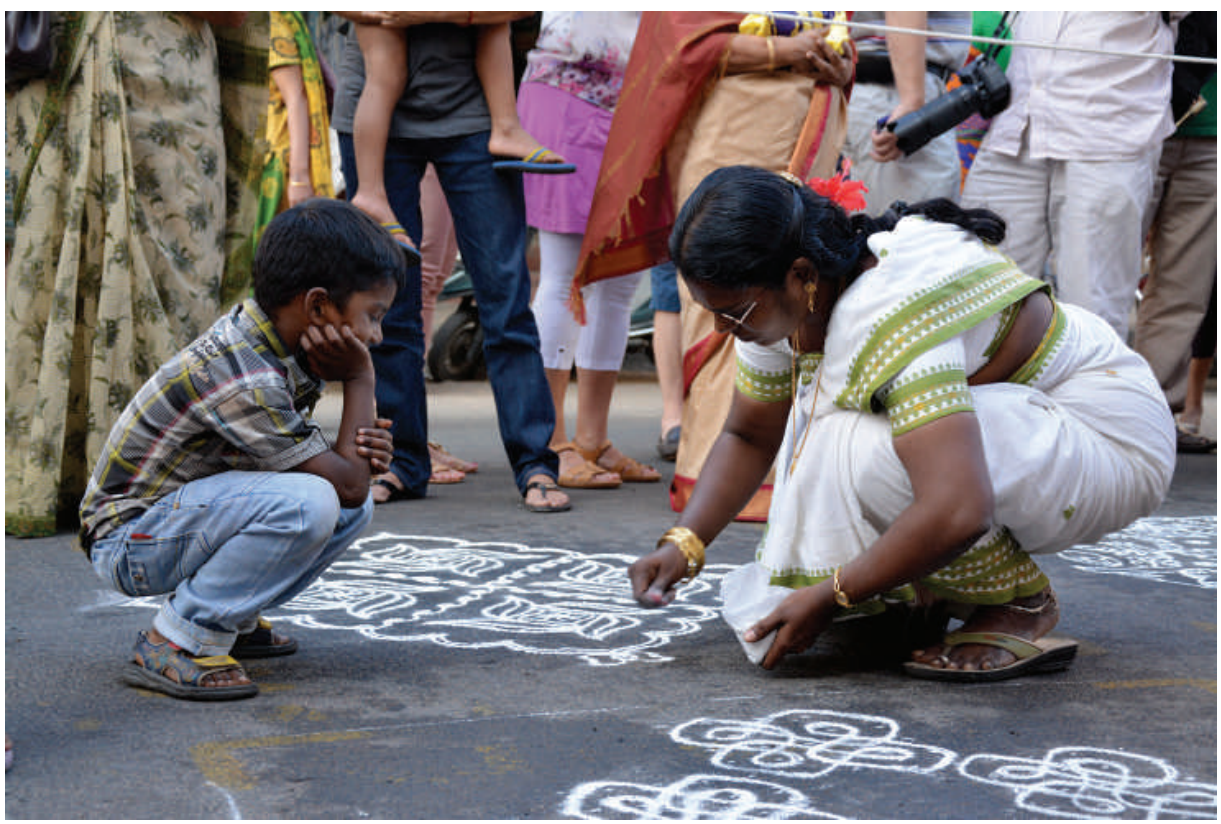

Mujer realizando un kolam en la Competencia Anual de Kolam, en el Festival de Mylapore (Chennai), sur de la India. Fuente: Tazmpictures, 2014.

La segunda categoría de yantras está relacionada con la tradición tántrica del hinduismo y su metafísica, por lo que la podríamos catalogar como más compleja e interna que la descrita anteriormente, pero finalmente igual de sagrada y de relevante para el ceremonial hindú.

Pero ¿qué es el Tantra? Grosso modo, el tantra es un conjunto o red de muchos movimientos, que comparten el cuestionamiento y crítica a la sociedad tradicional de la India antigua, particularmente a los valores brahmánicos, y al principio de lo puro y de lo contaminante que lo sustenta. Por ello, el tantra presenta una nueva forma de vida religiosa y una nueva práctica espiritual, que son consideradas como transgresoras por el hinduismo ortodoxo. La tradición del tantra está fundamentada en los textos sánscritos denominados Tantras, que datan entre el siglo viI y viII de nuestra era, valorados por sus seguidores como revelación e incluso superior a los Vedas. El académico Gavin Flood, en su obra El Hinduismo, explica que:

Los Tantras son rechazados por la ortodoxia védica, sin embargo, sus seguidores, los tantrikas, incluyeron al sistema ortodoxo en la calidad mermada de nivel inferior de comprensión y capacidad. De alguna forma la revelación era progresiva, y los tantrikas auparon sus propios sistemas a la cúspide de una jerarquía de acceso a la sabiduría [...]. El Tantrismo ha tenido a partir del siglo XI una 
presencia tal que todo el hinduismo ha sufrido su influencia [...] absorbiendo todos elementos derivados de los Tantras.

Los Tantras destacan por sus elementos eróticos y antinómicos (la práctica del sexo ritual o el consumo de alcohol y carne ofrecidos a divinidades calientes o feroces), sin embargo, la mayor parte de su contenido resulta de naturaleza más sobria, incluyendo material que versa sobre una amplia gama de cuestiones. Aunque se trata de textos principalmente rituales, los Tantras también se interesan por explicar la formación de mantras, por presentar cosmologías estructuradas y jerarquizadas, por la evolución del sonido del nivel sutil al grosero, por las iniciaciones, por el yoga, la doctrina, el comportamiento correcto o la arquitectura de los templos (177-80).

Así tenemos que los rasgos más característicos que se destacan en los Tantras son los siguientes, aunque algunos no sean exclusivos de los Tantras y no en todos se contienen la totalidad de sus elementos:

- Los Tantras se interesan por la práctica espiritual, que implica la iniciación, el ritual y el yoga.

- Existe una estructura ritual común en los Tantras, la cual se puede resumir en que se produce la purificación del cuerpo por medio de su destrucción simbólica; posteriormente la creación un cuerpo o Yo divino por medio de los mantras; el culto o visualización interior seguida por la veneración o ritual exterior $(p \bar{u} j \bar{a})$. Este proceso incluye el empleo de gestos realizados con las manos (mudrā), la repetición de mantras y la construcción de diagramas sagrados (yantras).

- Los Tantras presentan cosmologías jerárquicas complejas que asimilan las jerarquías cósmicas de tradiciones anteriores.

- El cuerpo es divino y contiene la jerarquía cósmica en su interior, así como la polaridad cósmica formada por la divinidad masculina y su consorte, la energía femenina.

- Los Tantras se interesan por la consecución de poderes mágicos (siddhis) y el goce de la experiencia de felicidad en los mundos superiores como componentes de un camino espiritual, concebido y experimentado como el viaje de kuṇdalinī a través del cuerpo del adepto.

- Los Tantras se interesan por las prácticas de posesión y el exorcismo.

De este modo, para lograr una comprensión general de las bases de la metafísica del yantra en esta segunda naturaleza, se debe conocer necesariamente la doctrina tántrica de Śakti, una de las más importantes y reconocidas por su forma de representación y soporte filosófico de esta tipología del yantra. En esencia, Śakti, como energía cósmica creadora, es el poder presente en todo el universo y en sus múltiples manifestaciones, que representa las fuerzas dinámicas de la naturaleza, personificadas en el aspecto femenino de la divinidad. A su vez, es la contraparte $y$, al mismo tiempo, el 
complemento de las fuerzas pasivas de la naturaleza, representadas en el aspecto masculino de la divinidad (Śiva). La teología de Śakti se ramificó, principalmente, en dos grandes corrientes: las escuelas de la Diosa feroz y negra Kālī, y la de la Diosa benévola y suave Śrī Vidyā, que veneran a la Diosa Lalitā Tripurāsundarī, "La Bella Diosa de las Tres Ciudades". Ambas escuelas desarrollaron sus propias deidades auxiliares alrededor de sus divinidades centrales, y también idearon yantras que ilustran algunos de los conceptos filosóficos predominantes de sus sistemas de pensamiento respectivos.

El movimiento Śrī Vidyā se adaptó a los valores brahmánicos ortodoxos. Por el contrario, las tradiciones centradas en Kālì se interesaron menos por la ortopraxis, y mucho más por los poderes que podían adquirirse a través de actuaciones generadoras de impureza y opuestas a las normas sociales y religiosas aceptadas, identificándola con los distintos estados de conciencia. Así, a modo de ejemplo, en esta escuela hallamos por primera vez citados los seis centros clásicos -los c(h)akras- de la fisiología mística del Hinduismo (Flood 205).

Por su parte, Tripurāsundarī es venerada, generalmente, bajo la forma de un diagrama sagrado, un yantra de nueve triángulos entrelazados, denominado Śrī $C(h) a k r a$ o Śrī Yantra (fig. 9), el más importante y célebre de los novecientos sesenta yantras existentes, según el Tantraraja Tantra. La cosmología de la escuela Śrī Vidyā se simboliza completamente en este cosmograma, utilizado como foco de veneración e instalado en los templos, siendo este diagrama a la vez divinidad y representación del Cosmos.

Los elementos del Śrī Yantra típicos son:

a) Un doble marco cuadrado exterior, formado mediante líneas rectas quebradas conforme a una pauta regular, que simbolizan el cielo y la tierra, juntos.

b) Una serie de círculos concéntricos y dieciséis pétalos de lotos estilizados, que representan el poder del yogui sobre la mente y los sentidos. En el interior de este, se encuentra un loto de ocho pétalos que simboliza a la deidad Viṣnu.

c) Una composición concéntrica de nueve triángulos equiláteros que sirven de símbolo para lo divino. Los cuatro triángulos orientados hacia arriba representan el principio masculino presente en el universo, es decir Śiva, y los cinco triángulos orientados hacia abajo representan el principio femenino, es decir, Śakti. Todos estos triángulos emanan a partir del punto central (bindu), que representa la eternidad y el origen de toda manifestación, además de simbolizar en una primera etapa (para-bindu) el núcleo de la energía concentrada, condensando en él todos los aspectos dinámicos y estáticos de lo femenino y de lo masculino del universo. En una segunda fase (apara-bindu), cuando la creación ha comenzado ya, el punto central se (auto) transforma por el resultado de la relación de las energías dinámicas y estáticas (de los aspectos masculino y femenino), emergiendo dos puntos suplementarios que forman el triángulo primordial (mula-trikona), que representa la creación, preservación y la disolución, las tres cualidades principales de Śakti. 


\section{FIGURA 3}

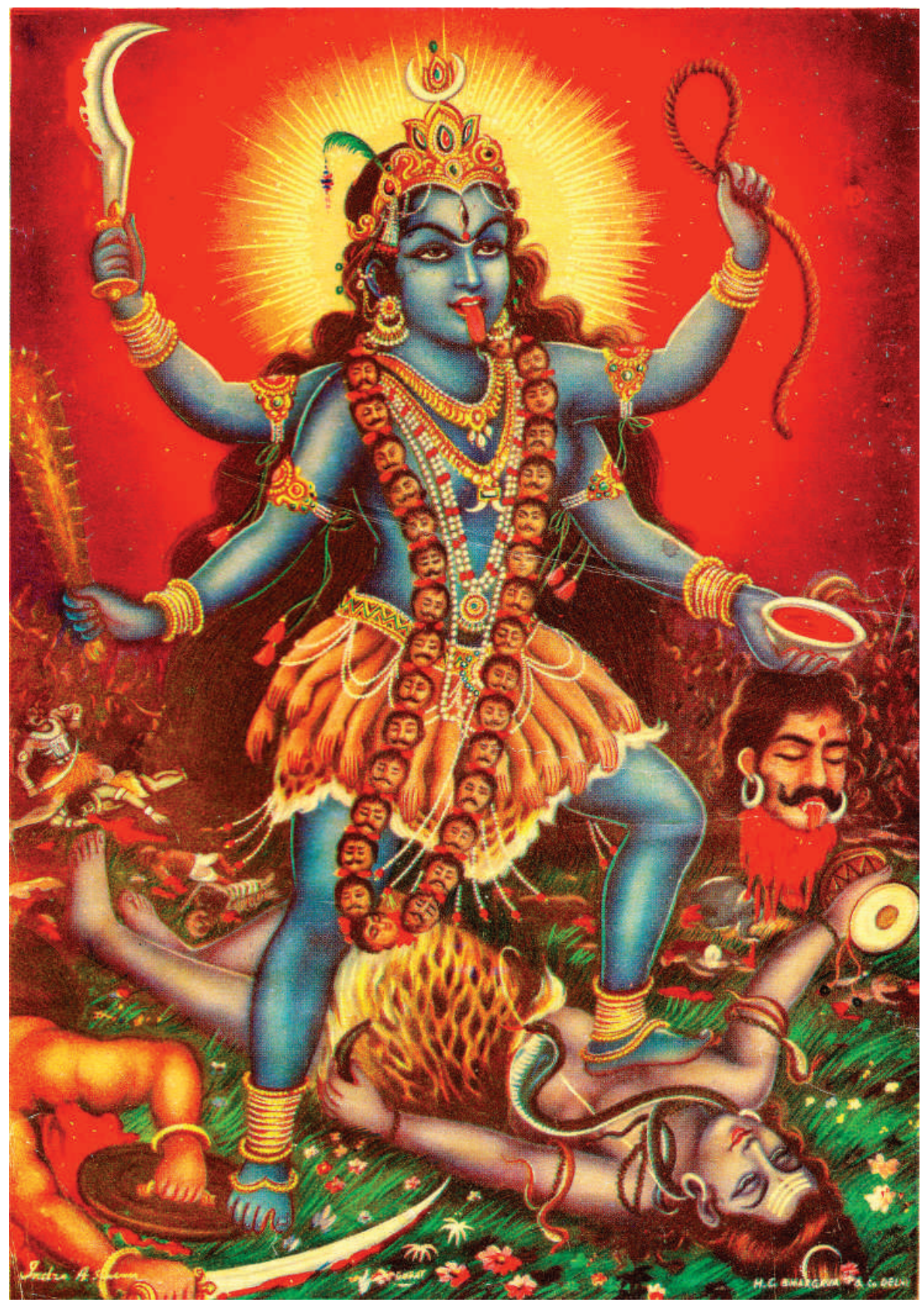

Diosa (devī) Kali. 
FIGURA 4

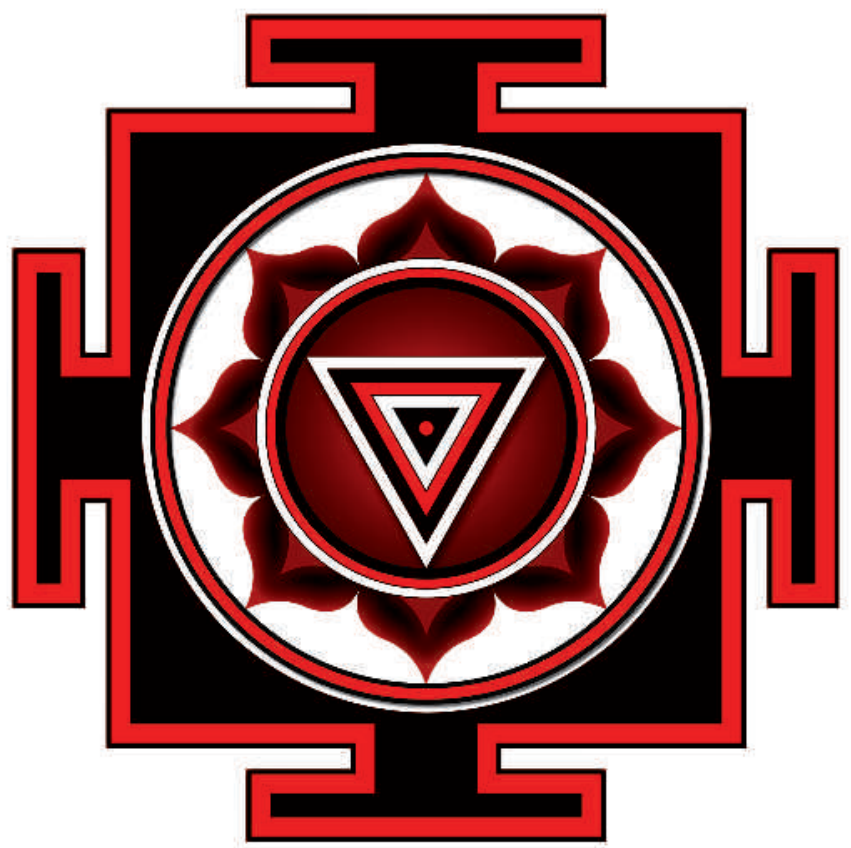

Diosa (devī) Lalitā Tripurāsundarī.

Figura 5

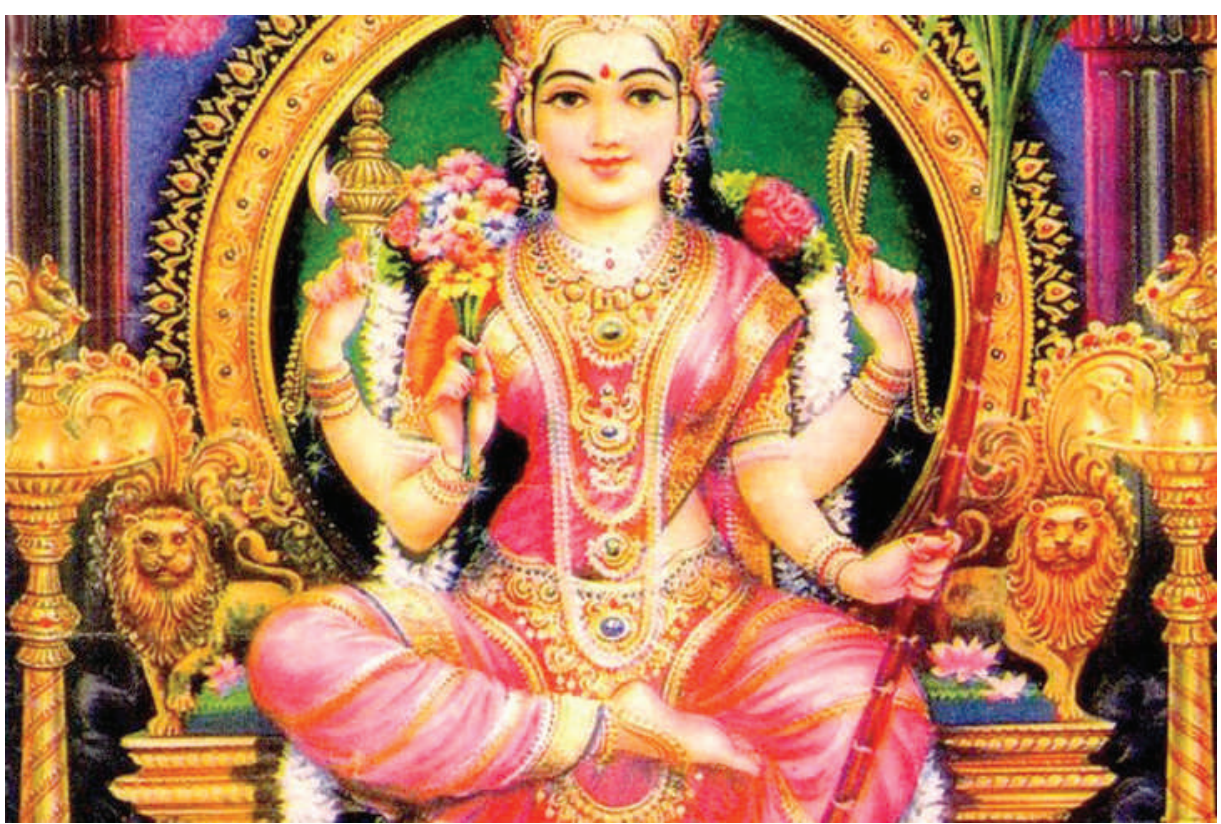

Kali Yantra. 


\section{FIGURA 6}

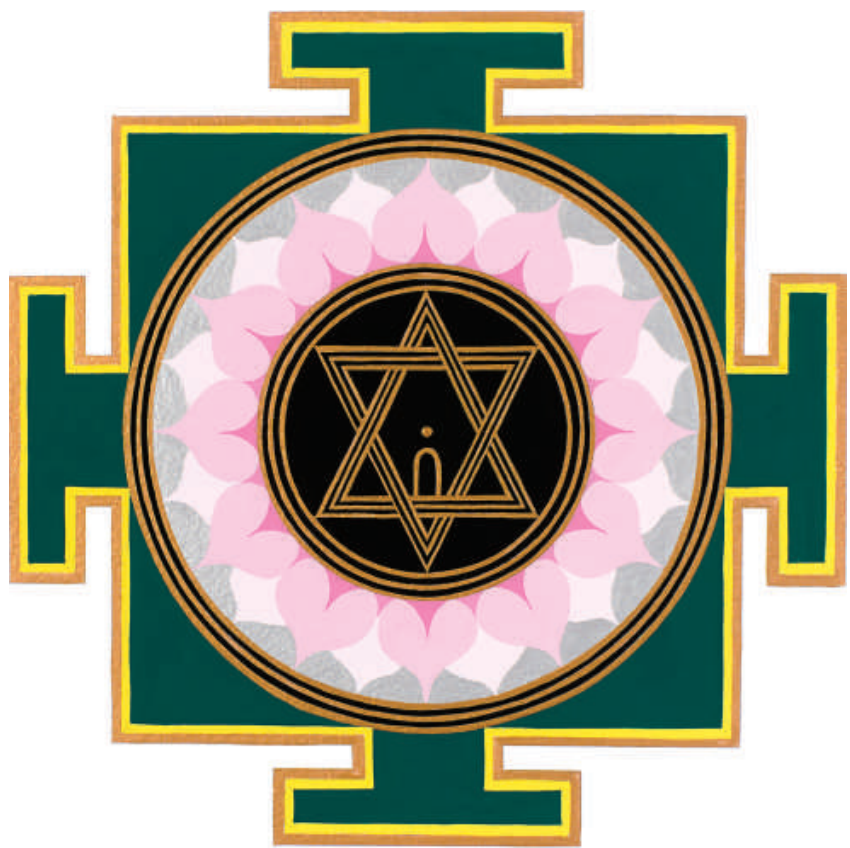

Tripurāsundarī Yantra.

\section{FIGURA 7}

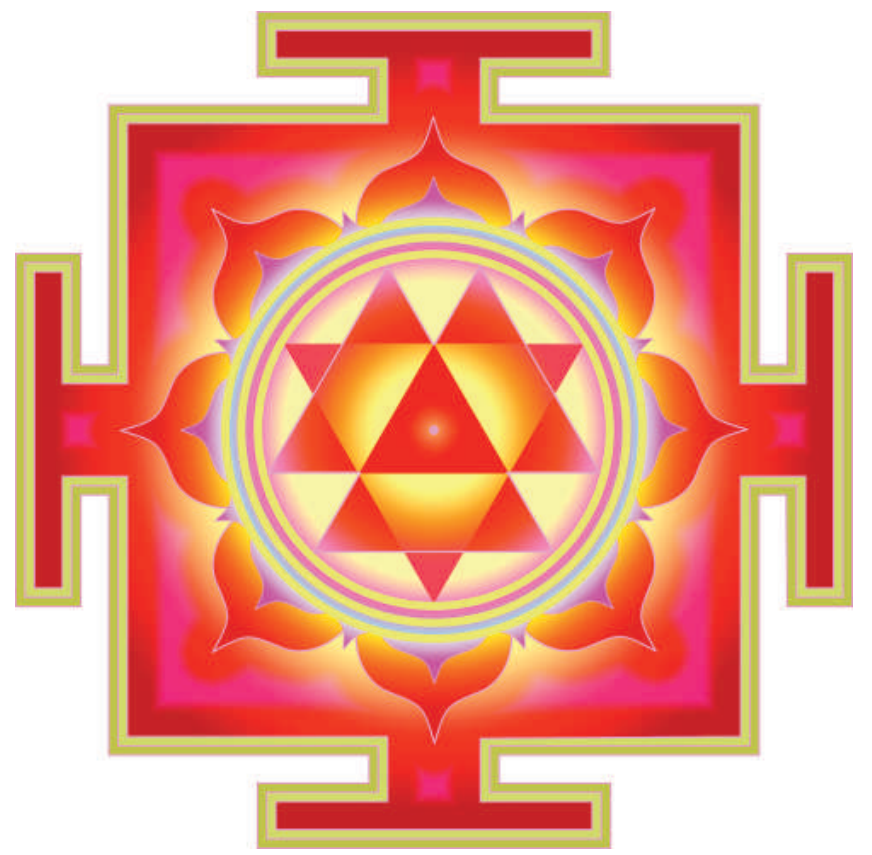

Gaṇeśa Yantra. 
FIGURA 8

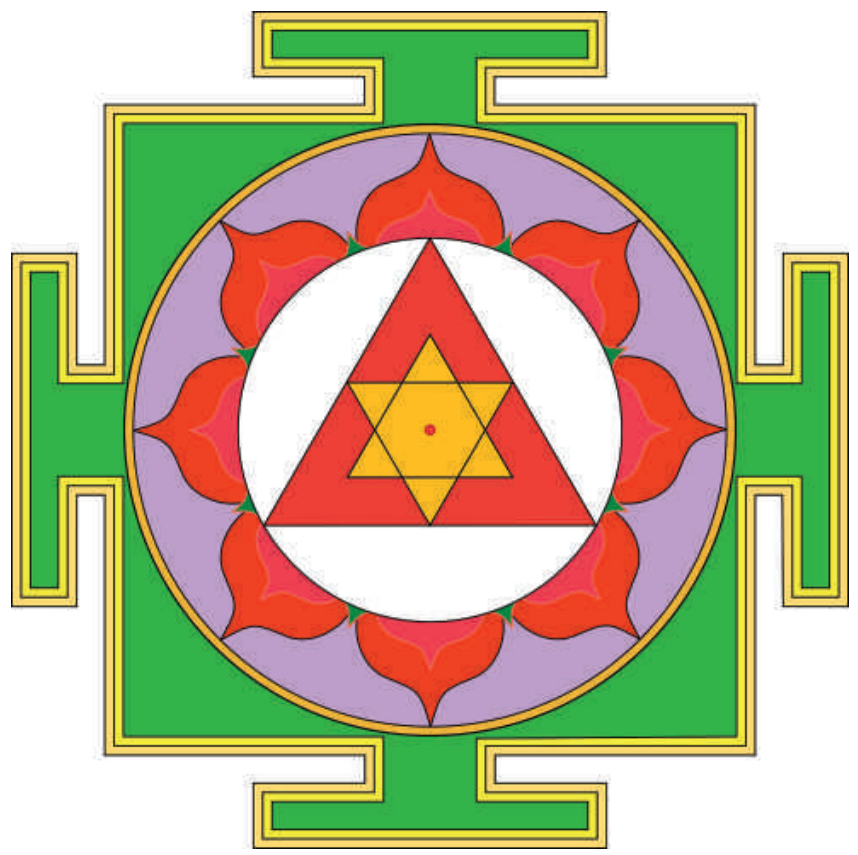

Durga Yantra.

FIGURA 9

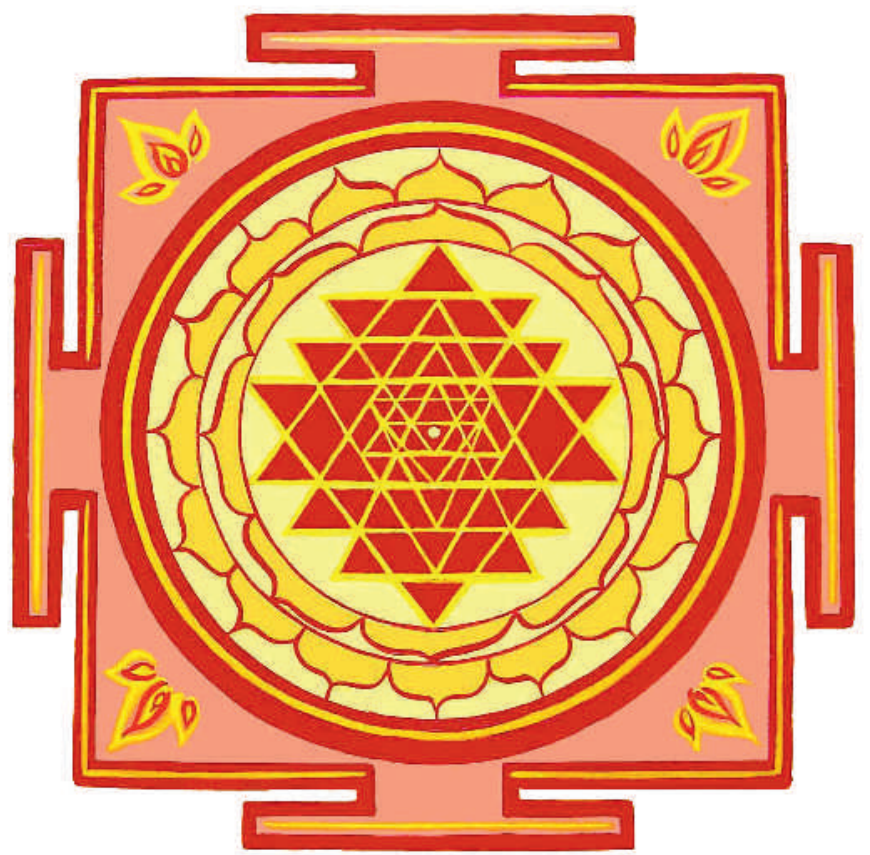

Śrī Yantra o Śrī C(h)akra. 
Así pues, su interpretación representa la unión de Śiva y la Diosa, lo masculino y lo femenino, fusión que el aspirante espiritual realiza en su interior por medio de una identificación ritual del Śrī Yantra con su propio cuerpo (Rawson 16-21; Jansen 10). Como señala Zimmer: "Este santuario es sede de la divinidad, y debe considerarse el centro del corazón del devoto. En él reside su deidad escogida particular, la cual, finalmente, debe ser entendida como una simbolización del núcleo divino de su propia existencia, de su Yo eterno y superior" (140).

Una vez construido el yantra, tanto material como mentalmente, el yogui lo va disolviendo de manera gradual, dejando que se revele a su visión interior, y luego concentrándose en ella. Debe dejarse imbuir de sus rasgos significativos y darse cuenta de que revelan la esencia divina, la verdad, la realidad esotérica de la naturaleza del universo y de su propio -y verdadero- ser. Finalmente, logra identificarse completamente con la figura escogida hasta el punto de no diferenciar si el yantra está en su interior o es él quien penetra en el yantra. Los practicantes de esta clase de ejercicios mentales de yoga afirman que, si se efectúa con éxito, este ejercicio catapultará al practicante hacia la conciencia pura, hacia la total unidad, más allá de la distinción entre sujeto y objeto, hacia sat-cit-ānanda, la cual es por esencia -y por derecho- nuestra verdadera -y divina- naturaleza.

\section{Palabras al cierre}

Quisiera terminar este breve y fragmentario trabajo del arte hindú y de los yantras con algunas pocas y simples ideas "sueltas" que afloran naturalmente, luego del tratamiento del tema en cuestión. Como todas las diferencias y similitudes, culturales o de otra índole, responden solo al grado de percepción que el hombre posee de sí mismo, a su autodefinición e individualización, es lógico concluir que producto de las distintas cosmovisiones que imperan en Occidente en contraposición a la preponderante en la India tradicional, nos encontremos también con distintas formas de concebir y calificar la espiritualidad y también la actividad artística, cualquiera sea esta (Eliade, Lo Sagrado 50-1). Esta es la principal razón de nuestras diferencias formales en el arte y también en cómo concebimos y entendemos el mundo.

La cultura occidental contemporánea ha puesto gran énfasis en todo lo referente al mundo externo y sensorial, relegando -en el mejor de los casos- para un segundo, tercer, e incluso cuarto plano, todo lo relacionado al mundo interior, es decir, la mente y sus herramientas de conocimiento no tienen mayor utilidad, sino donde solo importan la pura intuición y la percepción, manifestadas a través de los símbolos, único modo de ser representada y transmitida a los otros.

De este modo, no es de extrañar que, para el artista hindú, lo abstracto y lo concreto se mezclen invariablemente, sin existir grandes diferencias entre uno y otro, puesto que este arte participa profundamente de la vida como un todo, de la natu- 
raleza interior y exterior del ser humano. El arte hindú, de ese modo, es el reflejo de la naturaleza -de toda naturaleza, interna y externa-, al expresar la vitalidad de sus formas, su plasticidad llena de pasión, junto al éxtasis místico más refinado.

De igual manera, la representación de los dioses, en formas humanas y abstractas, simboliza que el mundo de la realidad interior difiere del mundo exterior, pero no puede existir sin él. A diferencia de India, Grecia tomó como ideal el cuerpo físico, atlético, disciplinado, y presentaba la belleza del hombre de proporciones perfectas. Por el contrario, la India modeló su visión interior de las formas sutiles nacidas de la meditación por la apariencia física de los seres divinos que venera; no ha intentado nunca expresar la belleza física en sí, puesto que siempre ha considerado que la materia, en este plano, era solo una sombra burda y maciza al lado de las gloriosas realidades de los planos divinos. Para el arte hindú, la verdadera belleza no puede ser meramente corporal (Coomaraswamy, La Transformación 66-7).

En tal sentido, solo por un cambio de punto de vista, equivalente psicológicamente a una total desacralización formal, el adorador -que naturalmente considera el ícono como una utilidad devocional- llega a considerarlo como una simple obra de arte que, como tal, ha de ser estimada solo desde el punto de vista de la sensación -según los parámetros occidentales contemporáneos-. Inversamente, el moderno esteta, el filósofo o historiador del arte, que se interesa solo por las superficies y sensaciones, es incapaz de concebir la obra como el producto necesario de una determinación dada, es decir, como dotada de un propósito y una utilidad. De estos dos, el adorador, para quien se hizo el objeto, está más cerca de la raíz de la cuestión que el esteta, quien se esfuerza en aislar la belleza de la función.

Así, para todo el arte hindú, tanto en el icono antropomórfico como en los yantras -e incluso en los mantras-, representan mucho más que un objeto físico y concreto, ya sea en su aspecto visible o auditivo. Es, ante todo, un medio de meditación y de introspección, de sabiduría de la verdad última y suprema y, por supuesto, de placer, pero no solo sensorial, sino que del más alto, de beatitud infinita (ānanda) que, en cierta forma, organizan la mente y alma humana. Ese es el único sentido y fin que posee el arte tradicional hindú, y que tantas veces al espectador y crítico occidental le cuesta entender y, en consecuencia, disfrutar.

Solo cabe agregar que lo fundamental del arte hindú, de marcado tinte contemplativo y devocional, es que nos pone en contacto con esa esencia espiritual que siempre hemos sido, pero que hemos olvidado, despertando la realidad esencial que anhelamos y buscamos, y cuya nostalgia es una de las mayores angustias de nuestro tiempo. En suma, nos permite completarnos desde una dimensión inherente a nuestra naturaleza original, ver y vernos desde el "corazón iluminado". 


\section{Referencias}

Bäumer, Bettina, Alice Boner y Sadasiva Rath Sarma. Vastusutra Upanishad. The Essence of Form in Sacred Art. Delhi: Motilal Banarsidass Publishers, 1996. Impreso.

Biardeau, Madeleine. El Hinduismo: Antropología de una Civilización. Barcelona: Kairós, 2005. Impreso.

Boner, Alice, Sadasiva R. Sarma y Bettina Baumer. Vāstusūtra Upaniṣad. The Essence of Form in Sacred Art. Delhi, India: Motilal Banarsidass Publishers. Impreso.

Coomaraswamy, Ananda K. La Danza de Siva. Ensayos sobre Arte y Cultura India. Madrid. Siruela: 1996. Impreso.

---. La Transformación de la Naturaleza en Arte. Barcelona: Kairós, 1997. Impreso.

---. Sobre la doctrina tradicional del arte. Arte asiático. Barcelona: Ediciones de la Tradición Unánime, 1983. Impreso.

Deshapande, P.Y. El auténtico Yoga. Yoga-Sùtras de Maharishi Patañjali. Madrid: Kier, 2001. Impreso.

Eliade, Mirceau. El Yoga. Inmortalidad y Libertad. México, DF: Fondo de Cultura Económica, 1991. Impreso

---. Lo Sagrado y lo Profano. Barcelona: Paidós Orientalia, 2003. Impreso.

F. de Castro, Luis Osvaldo. El arte en la ruta del hombre. Santiago, Chile: Andrés Bello, 2001. Impreso.

Fernández, Ma. Rosa. "El juego dramático de la energía en el sivaísmo de Cahemira. Un estudio de estética comparada”. Tesis Doctoral, Departamento de Filosofía, Universidad de Málaga, 2000. Impreso.

Figueroa, Oscar. "Persuasión y mito en los orígenes del drama sánscrito. A propósito del primer libro del NĀTYYŚĀSTRA”. Habis 45 (2014). 151-165. Impreso.

Flood, Gavin. El Hinduismo. Madrid: Cambridge University Press, 1998. Impreso.

Jansen, Eva R. El libro de la imaginería Hindú. Diever, Holanda: Binkey Kok, 1993. Impreso.

Kandinsky, Wassily. Sobre lo Espiritual en el Arte. Buenos Aires: Need, 1997. Impreso.

Khanna, Madhu. Yantra: The Tantric Symbol of Cosmic Unity. Rochester, Estados Unidos: Inner Traditions, 2003. Impreso.

Kramrisch, Stella. The Vishnudharmottara Part III: A Treatise on Indian Painting and Image-Making. Calcutta: Calcutta University Press, 1928. Impreso.

Luarte C., Felipe. "El Hinduismo: Consideraciones Históricas y Conceptuales”. Revista Intus Legare 6/1 (2012). 45-62. Impreso.

Maillard, Chantal y Óscar Pujol. Rasa. El placer estético en la tradición india. Benarés: Indica-Etnos, 1999. Impreso.

Marchianò, Grazia. "Una búsqueda de un placer más elevado: el legado estético indio", Contrastes. Revista Internacional de Filosofía 9 (2004). 155-164. Impreso.

Masson, J.L. y M.V. Patwardhan. Śāntarasa and Abhinagupta's Philosophy of Aesthetics.

Poona: Bhandarkar Oriental Research Institute, 1969. Impreso. 
Merlo, Vicente. Simbolismo en el Arte Hindú. De la experiencia estética a la experiencia mística. Madrid: Biblioteca Nueva, 1999. Impreso.

Monier-Williams, Monier. A Sanskrit-English Dictionary. Delhi: Motilal Banarsidass Publishers, 2011[1899]. Impreso.

Pandey, Kanti Chandra. Comparative Aesthetics, vol. I. Varanasi: Chowkhamba, 1995. Impreso.

Rawson, Philip. Tantra. The Indian Cult of Ecstasy. London: Thames and Hudson, 1973. Impreso.

Rivière, Jean Roger, ed. Historia General del Arte. El arte de la India, vol. xIx. Madrid: Espasa-Calpe, 1964. Impreso.

Rudy Jansen, Eva. El libro de la imaginería Hindú: Dioses, manifestaciones y su significado. Holanda: Binkey Kok, 1993. Impreso.

Samuel, Geoffrey. The Origins of Yoga and Tantra. Indic Religions to the Thirteenth Century. Nueva York: Cambridge University Press, 2008. Impreso.

Shattuck, Cybelle. Hinduismo. Madrid: Akal, 2002. Impreso.

Sivanananda (Swami). Shrimad Bhagavad Guita. Diálogos con lo Eterno. Madrid: Librería Argentina, 1999. Impreso.

Stoler Miller, Barbara. Exploring India's Sacred Art. Selected Writings of Stella Kramrisch. Delhi: Indira Gandhi National Centre for the Arts New Delhi y Motilal Banarsidass Publishers, 1994. Impreso.

Zimmer, Heinrich. Mitos y Símbolos de la India. Madrid: Siruela, 1997. Impreso.

Recibido: 13 octunbre 2016 Aceptado: 27 septiembre 2017 